\title{
Decolonising the Aceh Museum
}

\author{
Objects, Histories and their Narratives ${ }^{1}$
}

\author{
AJENG AYU ARAINIKASIH AND HAFNIDAR
}

The Aceh Museum, one of the oldest museums in Indonesia, was established during Dutch colonial rule. In this article the discussion of three objects of the colonial collections at the Aceh Museum (an ancient metal bell, colonial photographs and an old wooden weaving tool) illustrate the complexities of decolonising museums in a previously colonised country. As this practice varies, depending on whether the country was colonised or was a coloniser, this case study shows that in the Indonesian context, decolonising museums means featuring narratives from the local perspective, challenging colonial legacies (such as social segregation) and deconstruction of Indonesian postcolonial postcolonial official nationalist history.

Het Aceh Museum, een van de oudste musea in Indonesië, werd opgericht tijdens het Nederlands koloniaal bewind. In dit artikel wordt aan de hand van verschillende voorwerpen uit de collectie van het Aceh Museum (een oude metalen klok, koloniale foto's en een oud weefgereedschap) ingegaan op de dekolonisatie van musea in vroegere gekoloniseerde landen. Aangezien de dekolonisatie van musea afhankelijk is van het gegeven of een museum in een gekoloniseerd land staat of juist in een land dat koloniseerde, laat deze case study zien hoe het dekoloniseren van musea in Indonesië zou moeten plaatsvinden door middel van narratieven vanuit lokaal perspectief, het ter discussie stellen van koloniale erfenissen (zoals sociale segregatie) en het deconstrueren van de Indonesische, postkoloniale en officiële nationalistische geschiedschrijving.

\section{Prologue}

Decolonising museums varies, depending on whether the country was colonised or was a coloniser. In the Netherlands decolonising a museum entails confronting the dark sides of colonial history and conducting original 
research on colonial acquisitions, as well as acknowledging the history of 'the others' from multiple perspectives. The Rijksmuseum, the Tropenmuseum and the Bronbeek Museum in their present permanent exhibitions are cases in point. How are museums decolonised in a previously colonised country such as Indonesia?

Colonial and anticolonial mindsets continue to dominate Indonesian museums and exhibitions today. In displays of ethnographic collections, for example, Indonesian museums group Indonesian people by their ethnicities and regional origins. In 1979-1980 in the provincial museum standard guidelines, Moh. Amir Sutaarga, head of the Directorate of Museums from the Department of Education and Culture, indicated that antiquarian books (books published by Europeans in colonial times) could be used as references for museums. ${ }^{2}$ As a result, presentations of objects at many Indonesian museums continue to reflect European perspectives and derive from European colonial sources, which may also feature in their displays (e.g. photographs). Some museums focus more on the history of Europeans than on Indonesians. At the history museums the anticolonial mind-set of the war against the colonial power dominates, omitting other narratives (e.g. social history).

Decolonising in the Indonesian context therefore means that museums may present narratives from the local perspective, challenging colonial legacies such as social segregation and deconstructing writing on Indonesian postcolonial official nationalist history, which remains embedded in Indonesian society.

A case study from the Aceh Museum illustrates this aspect in greater detail. Digressing slightly from Jos van Beurden and Maarten Couttenier, who cover repatriation and provenance history of colonial objects in this Forum, in this contribution we will discuss museum theory and practice from the Indonesian perspective on decolonising the colonial collections at the Aceh Museum.

This contribution was inspired by the present-day Acehnese who still suspect that the Europeans took their cultural and historical objects from them and hide their heritage in museums in Europe. In 1998-1999, for example, when Aceh Governor Irwandi Yusuf visited the British Museum in London, he found no Acehnese coins, although coins from other Southeast Asian kingdoms were on display. Asking to meet the curator from the

\author{
addition, this research would not be possible \\ without the funding of Indonesia Endowment \\ Fund or Lembaga Pengelola Dana Pendidikan \\ (LPDP), which sponsored Ajeng Ayu Arainikasih's \\ $\mathrm{PhD}$ research both in the Netherlands and in \\ Indonesia. \\ 2 Pedoman Pembakuan Museum Umum Tingkat \\ Propinsi (Jakarta 1979/1980) 44-60.
}


Department of Coins and Medals, he was shown three boxes of Acehnese gold coins that were in storage. Irwandi Yusuf stated that he would request that the British Museum place the Acehnese coins on public display or otherwise send them back to Aceh. ${ }^{3}$

As Caroline Drieënhuizen argues in this Forum, claiming and returning cultural objects is an important issue in decolonisation. In addition to being conducive to acknowledging historical injustice and strengthening identity and historical awareness, returning objects repositions people and countries politically, socially and culturally with regard to power and equality.

In this contribution, however, we argue that decolonisation is not merely about repatriating objects. We believe that more in-depth research on the histories of colonial objects in Indonesian museums may further decolonise the mind-sets of Indonesians (here: the Acehnese). The Aceh Museum and three objects that are part of the museum's colonial collections (an ancient metal bell, colonial photographs and an old wooden weaving tool) will serve as case studies. As Walter D. Mignolo has argued, decoloniality or decolonial re-existence means decolonial healing of colonial wounds. ${ }^{4}$ Decolonising the Aceh Museum's colonial collections and deconstructing its storyline may thus heal the colonial wounds of the Acehnese.

\section{The Aceh Museum and its history}

In 1915, Governor Henri N.A. Swart opened the Aceh Museum in Kutaradja (presently Banda Aceh). The museum was in a traditional Aceh house, built in 1914 as an Aceh pavilion for the Colonial Exhibition in Semarang, Central Java. Friedrich Wilhelm Stammeshaus, a military officer who collected Acehnese cultural objects, was responsible for arranging the displays of his collections for the exhibition in Semarang. Afterwards, the museum retained these collections, and Stammeshaus became the museum's first curator. $^{5}$

As stated in an article in the Bataviaasch Nieuwsblad in August 1915, the museum featured fine Acehnese crafts and was well worth visiting. ${ }^{6}$ old

Teuku Dadek, Murizal Hamzah and Miswar Fuady, Kapten Teungku Agam: Jejak Irwandi Yusuf Gubernur Aceh (Banda Aceh 2017) 88-94.

4 Walter D. Mignolo, 'Coloniality is Far From Over, and So Must Be Decoloniality', Power and Other Things: Indonesia \& Art (1835-now) (Ghent 2017) 24-26.
5 John Klein Nagelvoort, 'Koloniale tentoonstelling 1914: Het ideale Atjeh', Geschiedenis Magazine 53:1 (2018) 26-27.

6 'Een Atjeh-museum', Bataviaasch Nieuwsblad, 10 August 1915. 


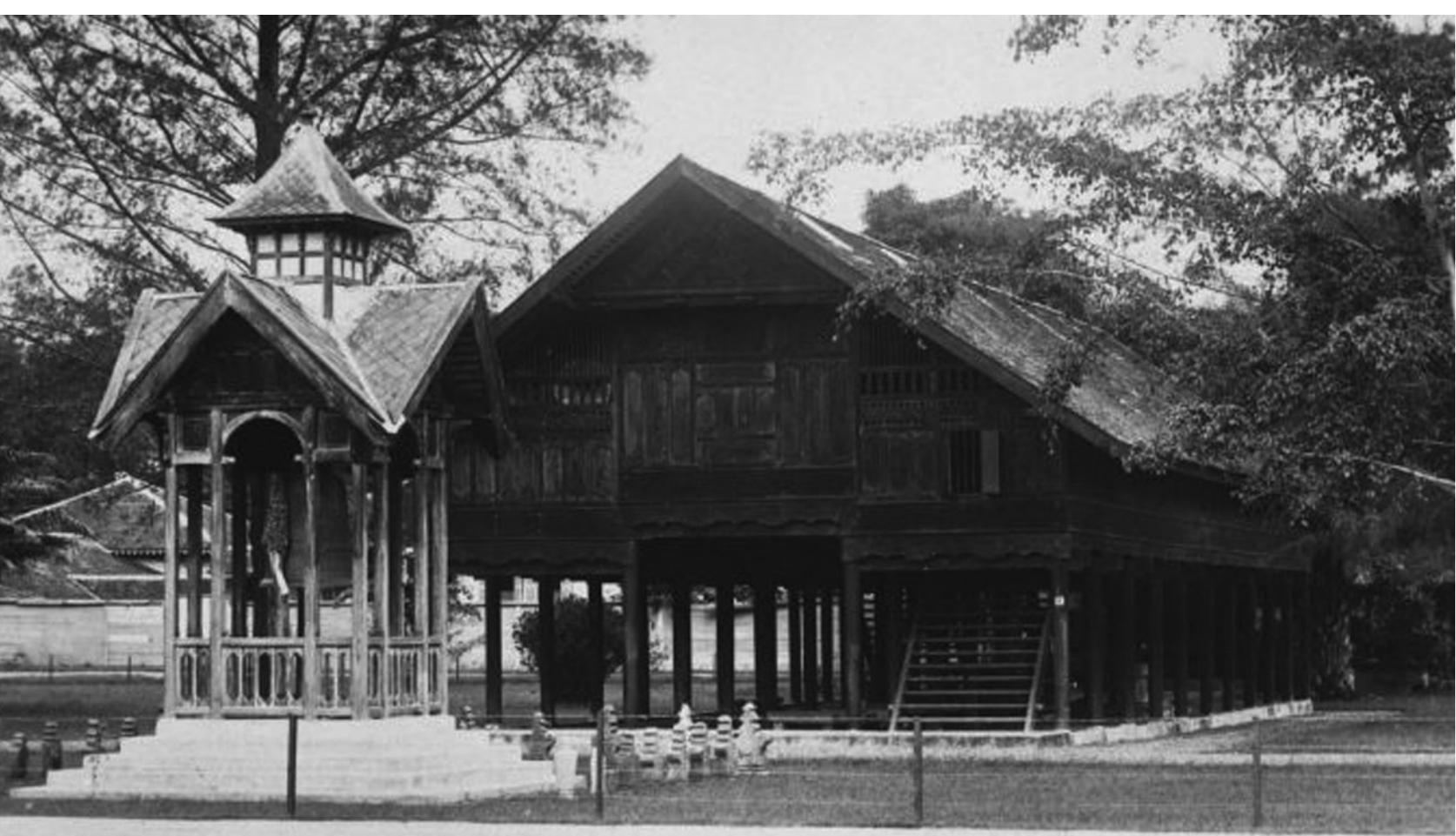

$\Delta$

The Aceh Museum c.1915-1930. Photo courtesy

of Wikipedia/Tropenmuseum. 
photographs reveal that these collections were displayed in vitrines in the Aceh house. The metal bell mentioned above has been clearly visible in the museum's courtyard since the colonial era.

In addition to the Stammeshaus collections, the museum acquired its own collections comprising 'old objects' taken from or given by local Acehnese. ${ }^{7}$ In 1931 Stammeshaus returned to the Netherlands. Although he intended to sell his collections to the Aceh Museum and leave them in Aceh, the Aceh governor at the time did not want to pay 5,00o guilders for the objects Stammeshaus had exhibited there. The Koloniaal Instituut in the Netherlands (presently the Tropenmuseum in Amsterdam) was interested in his collections and later bought them. The Stammeshaus collections previously on display at the Aceh Museum became part of the collections of the Koloniaal Instituut in the Netherlands, leaving the Aceh Museum to exhibit its own collections of ancient objects. ${ }^{8}$

After Indonesia became independent, the Aceh Museum was managed by the Badan Pembina Rumpun Iskandar Muda Pusat foundation, which in 1969 moved the museum to its present location. In 1974 the Aceh Museum received funding from the Indonesian Central Government to construct new structures in the museum complex, including a new permanent exhibition building. Later, in 1979, the Aceh Museum became a provincial museum under the auspices of the Indonesian Department of Education and Culture. ${ }^{9}$ At the time the Indonesian government aimed to establish new museums or transform existing ones into provincial museums in each province. ${ }^{10}$ All provincial museums had to meet specified standards. As at other Indonesian provincial museums, the new permanent exhibition at the Aceh Museum highlighted natural and cultural heritage in the province and Indonesian national identity through its collections. ${ }^{11}$

The Aceh Museum guidebooks published in 1982 and in 1994-1995 reveal the continuous storyline. Its permanent exhibition, spearheaded by the Directorate of the Museum, situated Aceh's history in Indonesia's natural environment, prehistoric era, pre-colonial civilisations, local colonial history and ethnography. Inside the old Aceh house, paintings of Acehnese heroes, household utensils and foreign ceramics and pottery were featured. The guidebooks also stated that colonial photographs of Acehnese heroes, Dutch military personnel

Koloniaal Instituut. Het Atjeh-museum en de collectie Stammeshaus', Algemeen Handelsblad, 11 April 1930.

9 Petunjuk Singkat Museum Negeri Aceh (Banda Aceh 1982) 14-19.
Cristina Faye Kreps, On Becoming 'MuseumMinded': A Study of Development and the Politics of Culture in Indonesia (University of Oregon, $\mathrm{PhD}$ thesis 1994) 146-147.

11 Pedoman Pembakuan Museum Umum Tingkat Propinsi, 25-30. 


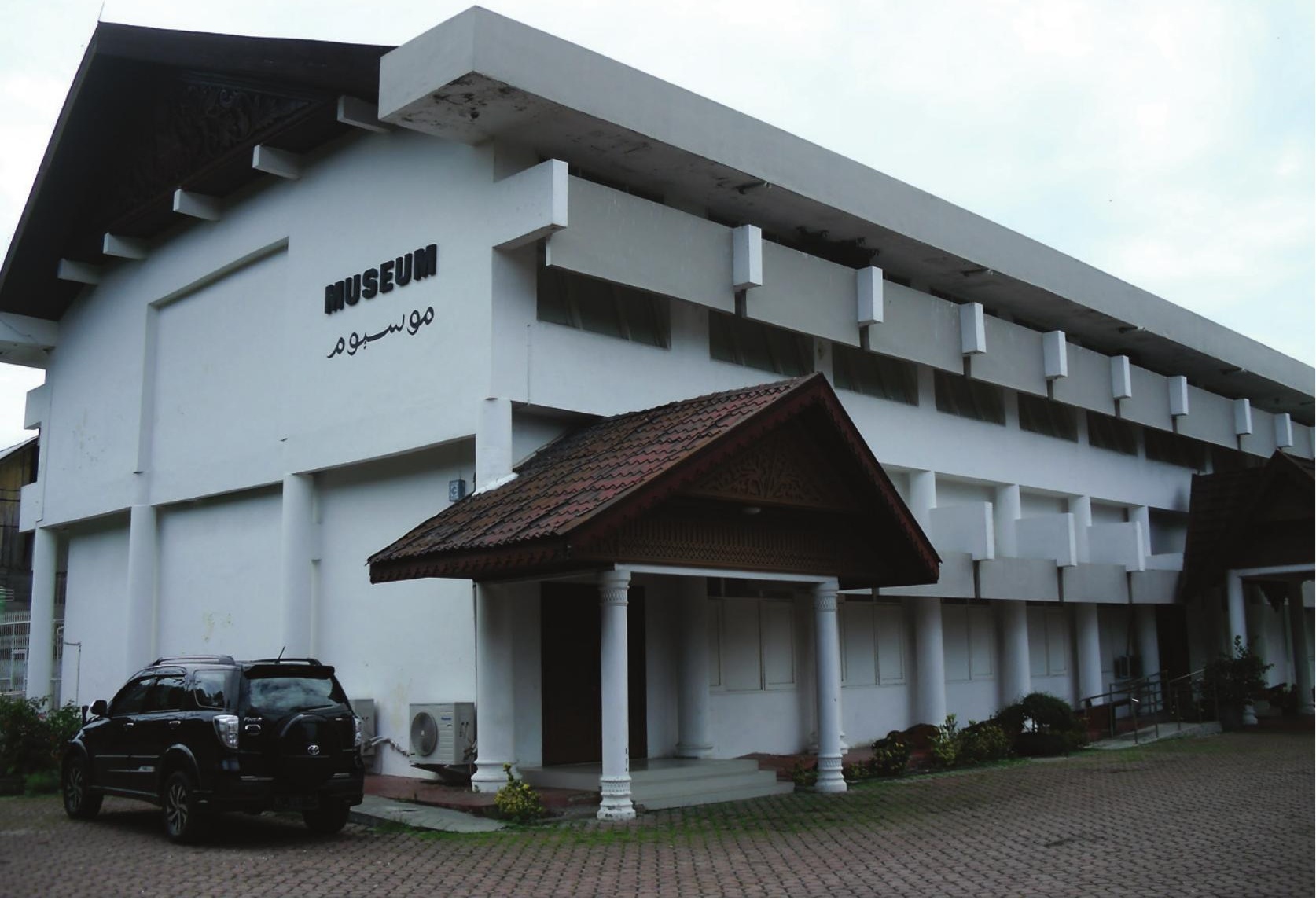

$\Delta$

The Aceh Museum's new permanent exhibition building. Photograph by Arainikasih, 2017. 
and Aceh military expeditions were displayed on the third floor. ${ }^{12}$ These are the colonial photographs that will be discussed later in this case study.

After Indonesian regional autonomy was established, the Aceh Museum was run by the Aceh provincial government. As the storyline did not change, the narrative of the Aceh Museum - under Indonesia's central government and under Aceh's local government - consistently featured Aceh's historic struggle against the Dutch and unity in diversity as the legacy of the New Order policy. Despite the widely known Free Aceh Movement or Gerakan Aceh Merdeka (GAM) during 1976-2005, it remained unclear whether this narrative was used intentionally or sub-consciously as propaganda against this local revolt.

In 2011 the museum again received project funding from the Indonesian Ministry of Culture and Tourism to revitalise its building and exhibitions. A third party renovated the new museum building and made new panels and vitrines to be installed later. In 2011-2014 the permanent exhibition was closed to the public. In 2015, to commemorate the museum's 1ooth anniversary, Hafnidar, curator of the Aceh Museum and co-author of this article, initiated the redesign of the permanent exhibition storyline.

The new storyline was developed along four main themes and was similar to the previous one, although it focused more on Aceh than on Indonesia in general. It highlights Aceh's natural surroundings, the history of past Acehnese Islamic kingdoms and Aceh as a place of resistance against colonial power and the local revolt, as well as Acehnese traditional cultures. Controversial themes such as the Gerakan Aceh Merdeka are represented within the museum's timeline by acknowledging their period in power and relating the story of their leader. The old Aceh house is now considered part of the museum collection and illustrates an Acehnese traditional house.

\section{The Cakra Donya bell: histories of inclusion}

The first object from the Aceh Museum colonial collection to be discussed here is an ancient metal bell of Chinese origin. This object has been selected to illustrate the efforts by the present day curator (Hafnidar) to make the museum more inclusive through its collection.

In the Aceh Museum courtyard there is a small wooden cupola that housed an ancient stupa-shaped metal bell called the Cakra Donya. This giant metal bell (h: $1.25 \mathrm{~m}, \mathrm{w}: 0.75 \mathrm{~m}$ ) has been part of the collection here since December 1915, when Governor Swart instructed a contractor to remove an ancient metal bell suspended from an old tree and place it in the museum courtyard. ${ }^{13}$ 


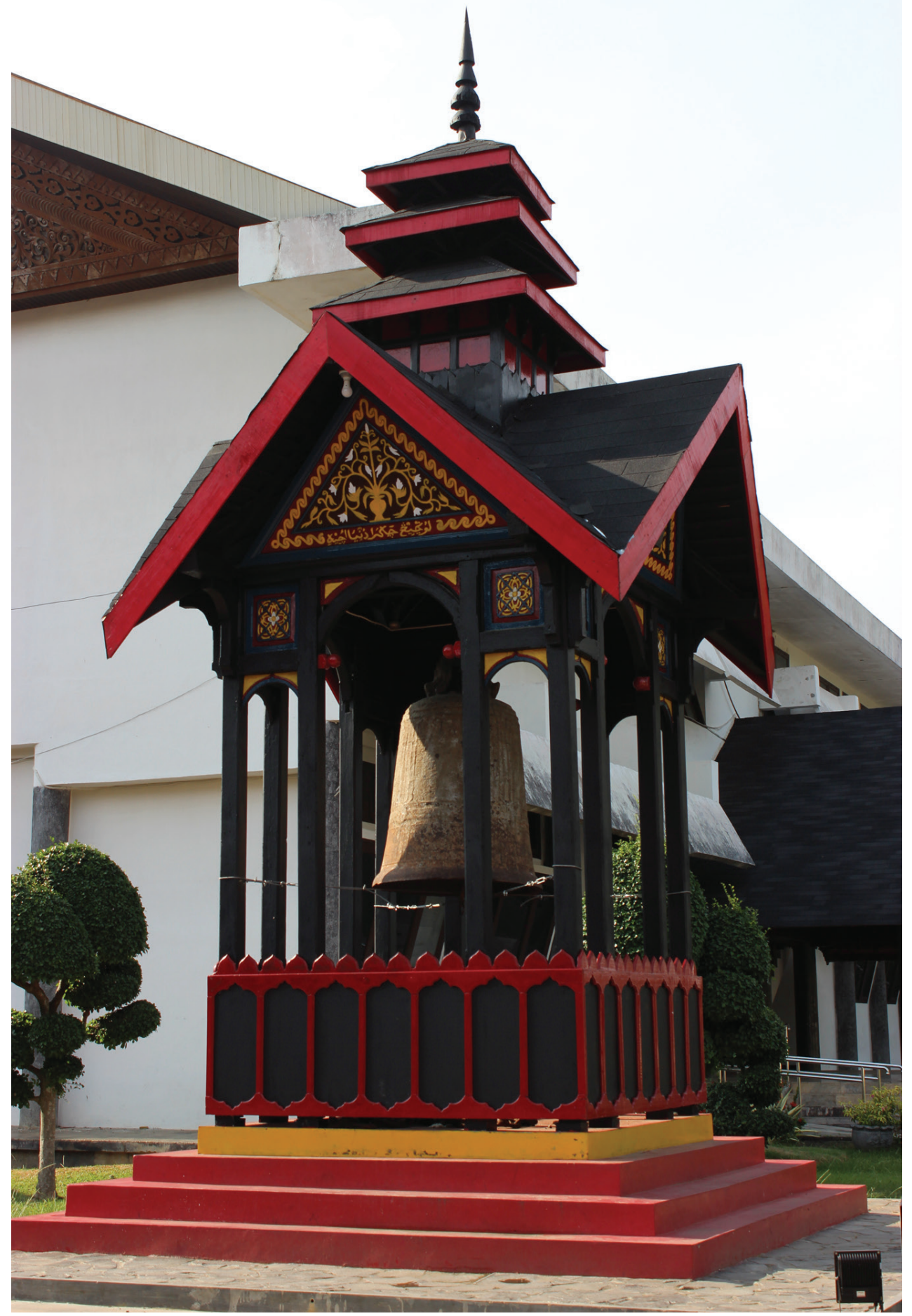


In 2015, while the museum was being redesigned, the curator changed the caption to the bell. The previous caption had described the Sanskrit meaning of the words cakra and donya, the appearance of the bell and its estimated year of origin (1409-1469), as well as its original location before transferred to the museum.

The current label opens with the statement that the bell is 'the harmonious symbol of the relationship between the Sultanate of Pasai and the Ming Dynasty'. The present-day museum label reads:

\section{In the fifteenth century, Admiral Cheng Ho gave the bell to the Sultan of Pasai during one of his 'friendship' expedition[s] to Aceh. In the sixteenth century, when Pasai [was] conquered by the Sultanate of Aceh, Sultan Ali Mughayat Syah brought the bell to the Aceh courtyard. In the seventeenth century Sultan Iskandar Muda of Aceh put the bell on his warship called the Cakra Donya. That is how the bell got its name. In the nineteenth century the bell was [suspended from] a tree and located in front of the regional Dutch office in Kutaradja. Then it was moved and became [part of] the collection of The Aceh Museum in December 1915.}

Because the bell was presented by Chinese Muslim Admiral Ceng Ho and had a Chinese inscription on the inside, the curator described it as a Chinese object representing the Chinese-Acehnese community. Based on a 1939 article by G.L. Tichelman, the Dutch are known to have ordered a Chinese contractor named Kok A Fie and his Chinese workers to move the bell from the old location to the museum. ${ }^{14}$ Therefore, when a Chinese television station interviewed the curator about ties between Aceh and China, she proudly mentioned the bell as a symbol of friendship between the two regions.

More recent preliminary research by the museum curator suggests, however, that the bell might not represent the Chinese-Acehnese community after all. In 2017 the curator interviewed some retired museum staff and some long-term staff to understand how visitors had viewed the bell in the past. She discovered that before the 1990s Acehnese people living outside Banda Aceh came to the museum and especially to the bell to pray. They would visit the bell and perform rituals nearby to pray for upcoming important events in their lives (e.g. a wedding). Others would pray for recovery from an illness. Based on G.L. Tichelman's report in 1939, such rituals already took place in 1939. The bell was seen as a sacred object by older Acehnese, and people brought offerings. Tichelman also wrote that Acehnese newlyweds came to the bell to request blessings to have many children. ${ }^{15}$

Why these practices have stopped remains unclear. What is clear, however, is that the people coming to pray here were not Chinese-Acehnese but Muslim (i.e. non-Chinese) Acehnese. The Cakra Donya bell may be more 
important for Muslim Acehnese than for non-Muslim Chinese-Acehnese, because it belonged to Acehnese sultans. The curator of the Aceh Museum then realised that the Chinese-Acehnese community was not represented in her museum. Due to Indonesia's present political situation, including the Chinese-Acehnese in the museum narrative is important.

The exclusion of Chinese-Indonesians may be traced back to the colonial era. As described by Bart Luttikhuis, in the colonial era, the Dutch segregated the Dutch East-Indies and divided social hierarchies into three classes: the Europeans and mixed-descent Indo-Eurasians (indisch), the timur asing or foreign Orientals (mostly Chinese and Arabs) and the native Indonesians (inlanders or pribumi). ${ }^{16}$

Thung Ju Lan wrote that the colonial government housed the Chinese in the Pecinan, separately from other local ethnic groups. At the time, the Chinese comprised two groups: the totok and the peranakan. The totok were recent arrivals from China, while the peranakan were born in Indonesia and had resided in the archipelago for generations. After Indonesia gained independence, the peranakan were considered integral to Indonesian society. Due to the Citizen Law in 1958 that forced the Chinese to choose between their Chinese citizenship and Indonesian citizenship, however, the peranakan became foreign subjects. This situation worsened after the pre-empted communist coup in 1965 and the subsequent violent regime change, when the New Order imposed in 1967 by President Suharto of Indonesia prohibited the Chinese from performing Chinese rituals and cultural customs. As a consequence, the peranakan Chinese continued to be considered foreigners until 2006, when legal reform by Indonesian President Abdurrahman Wahid brought modest improvement. ${ }^{17}$

When challenging the persistent colonial and New Order legacies for the Chinese-Indonesian peranakan in Indonesian society, museums need to feature the peranakan experience in their narratives. Examples include the stories of peranakan cultures and cuisines that have become part of Indonesian daily life or their role in the Indonesian independence movement. Segregating the pribumi (locals) from the Chinese-Indonesian community has become more of an issue following the recent blasphemy case involving former DKI Jakarta (Chinese) Governor Basuki Tjahaja Purnama. Presenting more inclusive histories has become still more critical for museums. As the Cakra Donya bell evidently does not represent the Chinese-Acehnese, the curator is exploring ways to add narratives that pay tribute to the Chinese-Acehnese to make the museum more inclusive. the Dutch East Indies', European Review of History: Revue européenne d'histoire 20:4 (2013) 539-558. DOI: $10.1080 / 13507486.2013 .764845$
17 Thung Ju Lan, 'Contesting the post-colonial legal construction of Chinese Indonesians as "foreign subjects"', Asian Ethnicity 13:4 (2012) 373-387. DOI: $10.1080 / 14631369.2012 .710075$ 


\section{Colonial photographs: decolonising the anticolonial}

The second case study concerns repatriation of colonial photographs to the Aceh Museum, as well as the image of Aceh as an anticolonial place due to its Aceh War past. The position of the curator on decoloniality as manifested by her selection of colonial photographs on display is covered as well.

During the redesign of the Aceh Museum in 2015, the curator added stories to twenty empty panels (provided by the museum's revitalisation contractor). She selected pictures and stories of ten Acehnese heroes and ten Dutch military generals and civilians and included less famous Acehnese heroes as well. The display comprises pictures of individuals rather than of Aceh military expeditions, although the scenes convey various historical events. Her simple objective in the decolonial healing was to show pride in the Acehnese rather than to depict them as a conquest by the Dutch.

Before the redesign photographs in the Aceh Museum included scenes of Aceh wars and military expeditions, as well as Dutch generals, KNIL soldiers and Aceh heroes. When this installation was dismantled during the museum's 2011 revitalisation, these pictures were placed in storage. While their source remains to be determined, they were definitely taken by Dutch photographers during the colonial era. Saifuddin Ibrahim, a retired staff member who worked in the exhibition department in the 1980 os and 1990s, stated in an interview that most of the colonial photographs featured in the special exhibitions were reproduced from an old history book, although he did not recall the title. ${ }^{18}$ The pictures in the old permanent display may therefore have been reproduced from a book as well.

Documents from 1975 and 1980, however, indicate that the Aceh Museum received old photographs from the Dutch retired Colonel J.H.J. Brendsen (1975) and the Bronbeek Museum in Arnhem (1980). Ten pictures from the Bronbeek Museum reveal Dutch military generals and missionaries who worked in Aceh during the colonial era. Twenty-six of the pictures from Colonel Brendsen, however, convey scenes from Aceh's colonial era (villages, railways and old monuments). The pictures received from the Bronbeek Museum were featured more prominently through the Aceh Museum's special exhibitions than the colonial scenes of Aceh provided by Colonel Brendsen.

This observation imbued the study by historian Jean Gelman Taylor. In 2005 she examined Aceh photographs at the KITLV as part of the 'Rethinking Indonesian Histories Project'. Taylor noted that pictures of war and resistance dominated representations of Aceh in museum exhibitions, history books and books about Indonesian art. Upon accessing 1,049 photos of Aceh at the KITLV, however, she found additional subjects, including Aceh's natural scenery, the sultan's palace and heirlooms, traditional houses and mosques, 
colonial buildings, locals and Dutch people in Aceh, Acehnese arts and crafts, plantations and mines, as well as infrastructures in Aceh. ${ }^{19}$

Representations of Aceh as a place of resistance against the colonial power seem embedded in Indonesian society as well. As historian Anthony Reid argues, this is a New Order legacy. Reid stated that the former Indonesian president Suharto identified armed struggle against Dutch rule as the unifying element in Indonesian history. During the era of New Order (Suharto) and official military historian and Minister of Education Nugroho Notosusanto, the historic struggle in Aceh against the Dutch featured prominently in history books, film and the national heroes programme. ${ }^{20}$ This colonial image of Aceh as a place of resistance against the Dutch resurfaces both intentionally and subconsciously in the Aceh permanent and special exhibitions at the Aceh Museum.

In his book Gagalnya Historiografi Indonesiasentris?! (2006), Indonesian historian Bambang Purwanto questioned whether the Indonesian nationalism that conveys anticolonial sentiment through portrayals of violence and fighting against the colonial power is still relevant in Indonesia today. ${ }^{21}$ The time has come for the Aceh Museum to rethink its storyline on the colonial and postcolonial eras. The museum could also deconstruct its storyline through the colonial photographs, for example, by the ones depicting Dutch servicemen. Instead of showing the conquest of the Acehnese, the storyline could communicate a more complex history, such as the concealed history of the Dutch KNIL soldiers, who were not only Europeans but also locals (e.g. Javanese, Menadonese, Ambonese) from other areas in the Dutch East Indies. Rather than promoting a sense of disparity between the Acehnese and the Indonesians elsewhere in this vast archipelago, this perspective would underline that history is not always 'black and white' between 'the bad and the good guys': history comes in many shades.

Another alternative is that instead of using colonial sources (e.g. history books and archives) to describe the photographs, the museum could conduct oral history research with the descendants of the local heroes in the pictures. As the Aceh Museum does not have any objects or regalia regarding Acehnese heroes, the curator plans to obtain collection acquisitions from their descendants. The museum's decision to portray less famous Acehnese heroes could also be considered a starting point and an application of Purwanto's theory. Purwanto has argued that alternative historiography, such as oral history and local history, have become more important for Indonesia's presentday historiography in order to solve the nation's more current problems. ${ }^{22}$

Perspektif Baru Penulisan Sejarah Indonesia (Jakarta 2013) 313-372.

Anthony Reid, 'War, Peace and the Burden of History in Aceh', Asian Ethnicity 5:3 (2004) 301314. DOI: $10.1080 / 1463136042000259761$.
21 Bambang Purwanto, Gagalnya Historiografi Indonesiasentris?! (Yogyakarta 2006) 50-87, 152-187.

22 Purwanto, Gagalnya Historiografi Indonesiasentris?! 152-187. 
Indonesia has a tendency to tell only the history of 'important' people, which Henk Schulte Nordholt describes as 'a history without people'. ${ }^{23}$ Conducting oral history research with local people and giving them opportunities to share their accounts of events or places in the past is therefore worthwhile. Aceh is not only about war and resistance, and portraying other dimensions of Aceh's colonial past is an alternative way to decolonise the mind-sets of the Acehnese today. In August 2018, for example, the Aceh Museum curator plans to organise a special exhibition on Acehnese woman and their crafts. She intends to use and decolonise colonial photographs that portray Acehnese woman in this exhibition, most likely by comparing Acehnese women from past and present.

\section{An old wooden weaving tool: collecting histories}

This final section is about the Aceh Museum's wooden weaving tool and the efforts by the curator to research its provenance as a colonial collection. The main purpose of this study is to learn more about Acehnese who worked with Stammeshaus and the museum in the past. In addition, she hopes to understand the collecting histories of the museum and the role of the Acehnese in these histories.

During the 2011-2014 revitalisation project, an old wooden weaving tool was dismantled and placed in storage. When the weaving tool was first displayed remains unclear: has it been featured since the colonial era, or was it added upon becoming a provincial museum with a new permanent exhibition? In 2015, when the museum curator redesigned the exhibition and wanted to restore the weaving tool on display, nobody knew how to reinstall it. The museum curator contacted Mrs Jasmani Daud, an Acehnese songket (traditional textile) weaver, and decided to re-create a new weaving tool based on the one that Mrs Jasmani Daud used. In the interest of making visits interactive, this new tool can be touched and lets visitors experience weaving textiles inside the exhibition gallery.

Approximately a year after the new weaving tool was put on display, John Klein Nagelvoort, an independent researcher from the Netherlands who works closely with the Aceh Museum curator, sent a photograph of a receipt from Stammeshaus. Generated in April 1928 and written in Indonesian, this receipt confirms that Stammeshaus paid 30 guilders for a weaving tool. This weaving tool had belonged to an Acehnese woman named Nyak Bidjak.

After receiving this note, the curator started to conduct research on the weaving tool. Together with Nagelvoort, she tried to trace the weaving 


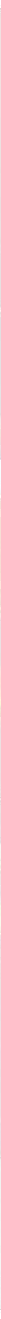

$\Delta$

A wooden weaving tool on display in the present Aceh Museum. Photograph by Arainikasih, 2017. 
tool by crosschecking the old museum registration number. She wanted to determine whether the weaving tool bought by Stammeshaus was the one in the museum repository. Nagelvoort argued that the tool on the receipt might be in the Netherlands.

The Aceh Museum curator also cross-checked the Acehnese names on the receipt. As Acehnese names usually include a royal title or reflect an area of origin, she inquired about their descendants. She found that genealogical research has become difficult to conduct in Aceh, as many families lost their old photographs in the tsunami in 2004. This research is still ongoing, and she does not yet have an answer.

As stories always focus on Stammeshaus and his collections, the curator is looking for the story from the Acehnese perspective and is tracing the history of collecting through oral history. This is an example of decolonising museums in a previously colonised country. Instead of using colonial sources to tell the stories of the objects in the museum, conducting research through oral history might explain the meaning or the history of an object from the local perspective. Researching the local point of view of colonial objects is a form of decolonisation and instead of narrating stories from the European perspective sheds light on the role of the Acehnese in their museum during the colonial era. Understanding the role of the Acehnese is an act of decoloniality. Challenging the imbalance of colonial power is also conducive to decoloniality. The input from Nagelvoort shows that such objects reveal various Dutch colonial and postcolonial and local Acehnese interests that extend beyond the physical objects.

In conclusion, some work remains to be done at the Aceh Museum, before the museum is decolonised, but much has been accomplished to date. Creating a more inclusive history, decolonising the anticolonial mind-set and researching the history of colonial and postcolonial collections and displays is leading to decolonial healing at the Aceh Museum. The work conducted at the Aceh Museum is important not only to decolonise the mind-set of present-day Acehnese but also to critique exhibition policies and practices in postcolonial and post-New Order Indonesia. This effort may also inspire other Indonesian museums to undertake similar projects and cultivate awareness that deconstructing and decolonising their collections and exhibition storylines may help decolonise the mind-sets of the people. It will also provide insight into what decolonising Indonesian provincial museums means.

\section{Epilogue}

In a private e-mail conversation, John Klein Nagelvoort (who will soon publish Toean Stammeshaus) mentioned plans to organise an exhibition about Stammeshaus in Indonesia at the end of 2018. Although these plans have not yet been finalised, the exhibition will be at the Aceh Museum in Banda 
Aceh. Nagelvoort hopes to develop the exhibition storyline together with the Aceh Museum. He suggests presenting a photo exhibition, as over fifty Aceh photographs are unknown, and perhaps including selected objects. Nagelvoort aims to show the public who F.W. Stammeshaus was. ${ }^{24}$

As discussed above, decolonisation in museums is clearly a different experience for the descendants of the coloniser than for the colonised people. We hope that researching the history of objects in the Aceh Museum and the upcoming exhibition will instrumentalise decolonising mindsets in the Netherlands and in Indonesia. The Aceh Museum curator would like the exhibition to convey Acehnese perspectives and interpretation by decolonisation of the colonial objects and photographs of Stammeshaus.

Ajeng Ayu Arainikasih (1983) is a PhD candidate at the Leiden University Institute for History. Her research is about colonial legacy, decolonisation and the representation of colonial past in the present-day display of Indonesian museums. After training as an archaeologist in Indonesia, she pursued higher education in Art History Curatorial and Museum Studies in Australia. She is also a lecturer at the Department of Archaeology Universitas Indonesia. Her expertise is in museum studies.

Email: arainikasih@gmail.com; a.a.arainikasih@hum.leidenuniv.nl.

Hafnidar (1976) is Curator and Head of the Museum Education and Collection Department at the Aceh Museum. Her educational background is in museology from Universitas Indonesia. At the Aceh Museum, her chief responsibility is running her department, particularly designing education programmes for schools, providing information to researchers and managing all the museum collections. Interested in all aspects of exhibition design, she redesigned the Aceh Museum's permanent exhibition and replaced its static approach with a more interactive concept. Her vision is to transform the Aceh Museum into an inclusive museum, where visitors of all ages enjoy unforgettable experiences while grasping the message of the exhibition.

Email: museumaceh@gmail.com. 